\title{
COMMENTS
}

\section{Implied Causes of Action Under Federal Statutes: The Air Carriers Access Act of 1986}

\author{
Nancy Eisenhauer $\dagger$
}

In 1986, Congress enacted the Air Carriers Access Act ("ACAA" or "the Act") in an effort to prohibit commercial air carriers from discriminating against the nearly five million disabled Americans who require access to air transportation annually. ${ }^{1}$ The main provision of the ACAA reads as follows: "No air carrier may discriminate against any otherwise qualified handicapped individual, by reason of such handicap, in the provision of air transportation." The Act defines a "qualified handicapped individual" as one who purchases a ticket, presents herself or himself for travel,

\footnotetext{
† B.A. 1989, The University of Chicago; J.D. Candidate 1993, The University of Chicago.

1 Air Carriers Access Act of 1986, 49 USC $\$ 1374$ (c) (1988). For the number of Americans who require access to air transportation, see 132 Cong Rec S 9901 (Jul 30, 1986) (statement of Senator Chafee). Congress enacted the Act in an effort to overturn the Supreme Court's decision in Department of Transportation v Paralyzed Veterans of America, 477 US 597 (1986) (permitting commercial air carriers that do not receive federal funds to discriminate against the disabled in the provision of air transportation). See 132 Cong Rec S 9899 (Jul 30, 1986) (statement of Senator Dole). For general information regarding the ACAA and the circumstances surrounding its enactment, see David B. Helfrey and Russell W. Piraino, Equal Access to Air Transportation-The Only Way to Fly, 8 L \& Inequality 469 (1990); George S. Petkoff, Recent Cases and Developments in Aviation Law, Part II, 56 J Air L \& Comm 491 (1990); Comment, The Struggle For Equal Access Includes Commercial Air Transportation, 30 Santa Clara L Rev 1007 (1990); Paul Stephen Dempsey, The Civil Rights of the Handicapped in Transportation, 19 Transp L J 309 (1991).

249 USC \$ $1374(\mathrm{c})(1)$.
} 
and meets reasonable contract requirements expected of all passengers. ${ }^{3}$

Whether the Act has improved the quality or availability of air transportation for disabled persons remains uncertain. ${ }^{4}$ But as one commentator observed, "[i]f you are a wheelchair user and travel even occasionally by air, it's a safe bet that you have had trouble on just about every flight you have ever taken."s One commentator has suggested that the Act has not achieved its goals, in part because of minimal public enforcement by the Department of Transportation ("DOT"), the agency charged with enforcing the Act. ${ }^{6}$

Current DOT regulations require carriers to post officials at eàch airport they serve to receive and resolve complaints regarding ACAA violations. ${ }^{7}$ If an airline does not satisfactorily resolve a complaint, the DOT may assess a fine not to exceed ten thousand dollars. ${ }^{8}$ However, these regulations and fines fall short of accomplishing the ACAA's goals.

Beginning in 1988, private parties began bringing civil actions against commercial air carriers in an effort to force the carriers to comply with the Act's prohibition against discrimination. ${ }^{\circ}$ However, the ACAA does not contain any provision that explicitly provides for or denies private enforcement actions. ${ }^{10}$ This Comment addresses two questions: whether courts may imply a private cause of action under the Act and, if so, whether they may award damages for emotional distress and punitive damages.

Of the three cases that have raised the question of an implied private cause of action and available damages, ${ }^{11}$ two reached the appellate level: one in the Fifth Circuit ${ }^{12}$ and one in the Eighth Circuit. ${ }^{13}$ The third awaits appeal in the Tenth Circuit. ${ }^{14}$ In each

${ }^{3} 14 \mathrm{CFR} \S 382.5$ (1992).

4 See David M. Capozzi, The Disabled Fly in Unfriendly Skies, 71 Bus \& Soc Rev 22, 26 (Fall 1989).

${ }^{5}$ Id at 22 .

- Comment, 30 Santa Clara L Rev at 1033 (cited in note 1).

? 14 CFR \& 382.65 (1992).

- Federal Aviation Act of 1958, 49 USC § 1471(a)(1) (1988).

- As suggested in Capozzi, 71 Bus \& Soc Rev at 22, 26, because the government failed to issue regulations to accompany the ACAA on time, plaintiffs began to bring lawsuits in hopes of improving conditions.

10 See 49 USC \$ 1374(c).

11 See Americans Disabled for Accessible Public Transp. (ADAPT) v Skywest Airlines, Inc., 762 F Supp 320 (D Utah 1991); Shinault v American Airlines, Inc., 936 F2d 796 (5th Cir 1991); Tallarico v Trans World Airlines, Inc., 881 F2d 566 (8th Cir 1989).

12 Shinault, 936 F2d 796.

${ }^{23}$ Tallarico, 881 F2d 566.

14 ADAPT, 762 F Supp 320. 
case, the respective court implied a private cause of action under the Act. ${ }^{15}$ Each appellate court granted compensatory damages, including damages for emotional distress, but failed to reach the issue of the availability of punitive damages. ${ }^{16}$ In contrast, the district court in the third case, though it assumed that a private cause of action existed, held that neither damages for emotional distress nor punitive damages were available under the Act. ${ }^{17}$

These three cases raise several issues that merit analysis. To begin, the appellate courts' failure to reach the issue of punitive damages leaves open the question whether punitive damages are available under the Act. The conflict between the appellate courts and the district court on the issue of damages for emotional distress also raises the question whether such damages are available under the Act. In addition, an analysis of the appellate courts' reasoning ${ }^{18}$ raises the question whether the courts were correct to imply a private cause of action.

To analyze these issues, one naturally looks to cases that have implied private causes of action under other federal statutes. The Supreme Court has created two distinct tests to guide lower courts in this endeavor. ${ }^{10}$ In 1975, for example, the Court established a four-pronged test in Cort $v$ Ash. $^{20}$ The two appellate courts that have construed the ACAA based their decisions to imply a private cause of action on the Cort test. ${ }^{21}$ Although use of the Cort test may be appropriate in some cases, it should not be used to interpret the ACAA. Because the Cort test requires a less rigorous investigation into legislative intent, courts should use the test established in Transamerica Mortgage Advisors, Inc. $v$ Lewis ${ }^{22}$ to interpret the ACAA. Thus, it is important to examine the ACAA in light of the more stringent Transamerica test to determine whether implication of a private cause of action is warranted..$^{23}$

\footnotetext{
${ }^{28}$ Shinault, 936 F2d at 800; Tallarico, 881 F2d at 570. In ADAPT, the court assumed that a private cause of action existed. The point was never explicitly contested or addressed, although the issue of damages in response to a private cause of action was discussed. See $A D A P T, 762$ F Supp at $326-27$.

16 Shinault, 936 F2d at 804; Tallarico, 881 F2d at 572.

17 ADAPT, 762 F Supp at 327.

18 Because the district court in $A D A P T$ assumed that a private cause of action existed, its reasoning cannot be analyzed. See note 15 .

19 See, for example, Texas \& Pacific Ry. $v$ Rigsby, 241 US 33 (1916); Cort $v$ Ash, 422

US 66 (1975); Transamerica Mortgage Advisors, Inc. v Lewis, 444 US 11 (1979).

20422 US at 78.

11 Shinault, 936 F2d at 800; Tallarico, 881 F2d at 568-70.

22444 US 11.

${ }^{23}$ See notes 100-102 and accompanying text.
} 
These implication cases also pose a larger question concerning methods of interpretation. Plaintiffs in implication cases ask courts to imply private causes of action and corresponding damages under federal statutes containing no explicit direction on either issue. In answering the question whether a private cause of action and damages are available under the ACAA, this Comment will demonstrate the method of analysis that courts should use when confronted with the same question under other federal statutes.

Section I briefly reviews the relevant case law concerning the ACAA. Section II discusses two standards of interpretation and one canon of construction that should govern analysis of implication issues within the context of the ACAA and statutes generally. Section III uses the standards of interpretation and the same canon of construction to determine whether a private cause of action is available under the Act. Section IV inquires whether damages for emotional distress and punitive damages are available, applying both the proposed canon of construction and an alternative method. The Comment concludes that private causes of action and damages for emotional distress are available under the Act while punitive damages are not.

\section{Relevant Case Law}

Private plaintiffs have brought civil actions to enforce the ACAA on three separate occasions. This Section of the Comment briefly describes the facts of each case to highlight the difficulties people with disabilities ${ }^{24}$ face in air travel. It then discusses the courts' reasoning concerning an implied private cause of action under the Act. It concludes with a discussion of the courts' reasoning concerning the implication of damages for emotional distress and punitive damages.

In Shinault $v$ American Airlines, Inc., ${ }^{25}$ the defendant airline denied a man with quadriplegia access to one of its flights. The Fifth Circuit held that a reasonable jury could conclude that the air carrier in question had violated the Act by intentionally discriminating against Shinault. ${ }^{26}$ Ironically, the airline's conduct

\footnotetext{
24 The terms and phrases used in this Comment to describe people with disabilities were taken from Guidelines for Reporting and Writing About People With Disabilities, (The Research \& Training Center on Independent Living, 4th ed 1990).

2s 936 F2d 796.

${ }^{26}$ Id at 800 . All parties agreed that the plaintiff qualified as an "otherwise qualified handicapped individual" because he was accompanied by a nondisabled adult. Id. Note that recent revisions to the regulations no longer require a nondisabled escort. See text accompanying note 3 .
} 
caused Shinault, a representative of the Easter Seals Foundation, to miss a press conference intended to raise public awareness of the obstacles and issues that people with disabilities face. The airline's actions and procedures for dealing with the disabled caused Shinault to miss a connecting flight and forced him to wait in the airport for five hours without his personal equipment. ${ }^{27}$ Although the airline supplied him with a wheelchair, Shinault feared that he would suffer physical injuries without his personal wheelchair and other needed equipment. ${ }^{28}$

In Tallarico $v$ Trans World Airlines, Inc., ${ }^{29}$ the Eighth Circuit held that a reasonable jury could conclude that the defendant airline had intentionally discriminated against a thirteen-year-old with cerebral palsy when it denied her access to one of its flights. ${ }^{30}$ The plaintiff intended to fly from her school in Texas to her home in St. Louis for the Thanksgiving holiday. Because the airline agents would not allow the plaintiff to board the plane alone, her father flew to Texas to accompany her home on a later flight. Fearing similar treatment on the return trip, the plaintiff's father also accompanied her on the return flight.

In the third case, ADAPT $v$ Skywest Airlines, Inc. ${ }^{31}$ the district court granted partial summary adjudication to a defendant airline that had denied a wheelchair user access to one of its flights. The plaintiff, the Executive Director of the Salt Lake Citizens' Congress, intended to fly from Salt Lake City to a speaking engagement in Idaho. ${ }^{32}$ The airline refused to allow her to board the plane without a nondisabled adult, even though she claimed to be an otherwise qualified handicapped individual. The airline's refusal caused the plaintiff to miss her engagement. In addition, the airline refused to issue her a ticket for a future flight.

${ }^{27}$ Id at 799.

28 Id. Because the wheelchair the airline provided was low-backed and had neither seat belts nor other restraining devices, the plaintiff sat with his head propped up against a wall in order to maintain his balance. Shinault v American Airlines, Inc., 738 F Supp 193, 196 (S D Miss 1990). The plaintiff feared injuries from a fall from the wheelchair, pressure sores from the wheelchair, and dysreflexia or stroke from an inability to perform his bowel program. None of the injuries materialized.

28881 F2d 566.

so Id at 571. The court upheld the jury's finding that the plaintiff qualified as an "otherwise qualified handicapped individual" under the Act. Id at 569, affirming the finding reported in Tallarico v. Trans World Airlines, 693 F Supp 785, 790 (E D Mo 1988).

31762 F Supp 320.

32 Id at 322 . 
In the two appellate cases, the courts based their decisions to imply a private cause of action on Cort $v A s h,{ }^{33}$ which established a four part test for determining whether Congress intended to permit private enforcement under a federal statute. Under Cort, a court must examine: (1) the class the statute benefits, (2) the legislative history, (3) the statute's underlying purpose, and (4) the subject matter of the claim. ${ }^{34}$ After considering each of the four prongs of the Cort test, the appellate courts in the ACAA cases found that Congress intended to create a private cause of action pursuant to the Act. ${ }^{38}$

To determine the availability of emotional distress damages, the Eighth Circuit panel in Tallarico and the district court in $A D A P T$ drew analogies between the ACAA and other civil rights statutes. ${ }^{36}$ The $A D A P T$ court reasoned that since an analogous civil rights statute did not allow for the recovery of emotional distress damages, it was unlikely that Congress intended for the ACAA to provide for the recovery of such damages. ${ }^{37}$ The Eighth Circuit in Tallarico reached the opposite conclusion by drawing an analogy between the ACAA and civil rights statutes that did provide for damages for emotional distress. ${ }^{38}$ The Fifth Circuit in Shinault, finding analogies unhelpful, relied on Guardians Assn. $v$ Civil Service Comm'n of New York City ${ }^{38}$ to conclude that in the absence of contrary legislative intent courts should grant full relief, including damages for emotional distress. ${ }^{40}$ Finding no evidence of

ss Shinault, 936 F2d at 800; Tallarico, 881 F2d at 568-70.

34 Cort, 422 US at 78. See also notes $83-88$ and accompanying text.

${ }^{35}$ Shinault, 936 F2d at 800; Tallarico, 881 F2d at 570.

${ }^{36}$ Tallarico, 881 F2d at 570-71; ADAPT, 762 F Supp at 326-27.

37 ADAPT, 762 F Supp at 327. The court compared the ACAA to $\$ 504$ of the Rehabilitation Act. 29 USC $\$ 794$ (1988). The court also cited Tallarico, 693 F Supp at 790, Martin v Cardinal Glennon Memorial Hosp. for Children, 599 F Supp 284 (E D Mo 1984), and Marshburn v Postmaster General of the United States, 678 F Supp 1182, 1184-85 (D Md 1988), for the proposition that the Rehabilitation Act precludes the recovery of damages for emotional distress. $762 \mathrm{~F}$ Supp at 325 . At the appellate level, the Tallarico court found the reasoning behind these cases unpersuasive. $881 \mathrm{~F} 2 \mathrm{~d}$ at 570 . For cases that allow for the recovery of damages for emotional distress see note 146 .

ss 881 F2d at 570-71. The court compared the ACAA to the Civil Rights Act of 1866,42 USC § 1982 (1988); the Civil Rights Act of 1871, 42 USC § 1983 (1988); and the Fair Housing Act, 42 USC § 3601 et seq (1988).

${ }^{39} 463$ US 582, 595-96 (1983). Although this is also a case construing a civil rights statute, the Fifth Circuit relied on a rule of interpretation set forth in the opinion rather than on an analogy to the remedies the Court granted in the case.

10 Shinault, 936 F2d at 804. 
contrary legislative intent, the Shinault court held that Congress intended to permit emotional distress damages under the ACAA.41

The Shinault and Tallarico courts did not reach the issue of punitive damages because the plaintiffs had not alleged the type of wanton and malicious behavior required to support such damages. ${ }^{12}$ The district court in $A D A P T$ held that punitive damages were not available under the ACAA as a matter of law. ${ }^{43}$ The $A D A P T$ court based this holding on an analogy between the ACAA and another civil rights statute that did not permit recovery of such damages.4t

\section{Statutory Interpretation In Implication Cases}

Before a court can decide a question arising under a particular statute, it must determine the method of analysis it will use to interpret the statute. ${ }^{45}$ Because the two most common signposts of legislative intent, the statutory language and the legislative history, ${ }^{46}$ offer no explicit guidance to courts in implication cases, a well-defined analytical framework is particularly necessary. By definition, implication cases concern statutes that contain no explicit provisions regarding private enforcement. Remarking on the silence of the legislative history in such cases, the Supreme Court wrote, "[w]e must recognize ... . that the legislative history of a statute that does not expressly create or deny a private remedy will typically be equally silent or ambiguous on the question."17 Thus, courts need extra analytical guidance when interpreting statutes in implication cases. This Section sets forth two standards and a canon of construction that courts should use to analyze implication issues.

\section{A. Standards For Implication Cases}

A standard is a guide that directs a court's analysis of a specific question of law. ${ }^{48}$ For implication cases, the Supreme Court has created two standards to guide lower courts in answering the

4 Id.

12 Id; Tallarico, 881 F2d at 572.

13 ADAPT, 762 F Supp at 327.

14 See notes 36-38 and accompanying text.

45 See James Willard Hurst, Dealing With Statutes 31-32 (Columbia, 1982); Richard A. Posner, Statutory Interpretation-in the Classroom and in the Courtroom, $50 \mathrm{U}$ Chi L Rev 800, 800-02 (1983).

${ }^{18}$ Hurst, Dealing With Statutes at 56-57.

17 Cannon v University of Chicago, 441 US 677, 694 (1979).

1s See Richard A. Posner, The Federal Courts: Crisis and Reform 245 (Harvard, 1985). 
specific question whether the statute provides for private enforcement. The first standard requires that courts analytically separate two related questions: whether a private cause of action is available, and whether damages are available. ${ }^{49}$ Because courts consider similar evidence in deciding the two issues, separating the issues ensures that courts grant damages based on the available evidence and not simply on the contemporaneous decision to imply a private cause of action. ${ }^{80}$

The second standard provides that the implication of a private cause of action and damages depends on the intent of the legislature that enacted the statute. ${ }^{\sigma 1}$ Because Congress establishes statutory rights and obligations, courts may imply a private cause of action and damages only if they find that the enacting Congress intended to provide for such relief. ${ }^{52}$ Where intent is not explicit, courts can search for implicit indications of Congress's intent. The question of how to determine the implicit intent of a federal statute can best be answered by reference to a general tool of statutory construction-a canon, or rule of construction.

\section{B. Canons of Construction for Implication Cases}

Canons of construction are general rules that courts use to guide statutory interpretation. ${ }^{63}$ This Section focuses on one canon of construction, the "context canon," which courts should use to interpret the ACAA and other federal statutes when deciding implication issues.

\section{Canons in general.}

During the past four decades many legal scholars, including Karl Llewellyn and Richard Posner, have viewed canons as illegitimate creations of judges. ${ }^{54}$ These critics have argued that canons

48 See Guardians Assn. v Civil Service Comm'n of New York, 463 US at 595 (1983), quoting Davis $v$ Passman, 442 US 228, 239 (1979) ("Whether a litigant has a cause of action 'is analytically distinct and prior to the question of what relief, if any, a litigant may be entitled to receive." ").

so See Davis, 442 US at $239-40$ n 18.

${ }^{31}$ See, for example, Transamerica Mortgage Advisors, Inc. $v$ Lewis, 444 US 11, $15-16$ (1979); Touche Ross \& Co. $v$ Redington, 442 US 560, 568 (1979); Cannon, 441 US at 688; Cort, 422 US at 68-69; Texas \& Pacific Ry. $v$ Rigsby, 241 US 33, 39 (1916).

${ }^{52}$ See cases cited in note 51 .

ss See Hurst, Dealing With Statutes at 56 (cited in note 45).

s See Karl N. Llewellyn, Remarks on the Theory of Appellate Decision and the Rules or Canons About How Statutes Are to be Construed, 3 Vand L Rev 395 (1950); Posner, 50 U Chi L Rev 800 (cited in note 45). 
are merely mechanical justifications for substantative decisions, or that they are contrivances that falsely impute omniscience to Congress. ${ }^{58}$ These scholars have suggested that courts should abandon canons and search for other methods of statutory interpretation. For example, Karl Llewellyn suggested that courts should "strive to make sense as a whole out of our law as a whole." Judge Posner offered an "attitude" or "slogan" suggesting that "the task for the judge called upon to interpret a statute is best described as one of imaginative reconstruction. The judge should try to think his way as best he can into the minds of the enacting legislators and imagine how they would have wanted the statute applied to the case at bar." 58

Although these criticisms merit reflection, it is important to note that the Supreme Court has continued to rely on canons of construction even in the face of this body of criticism. ${ }^{59}$ While the Supreme Court has never explicitly responded to the critics' arguments, other legal scholars have offered convincing arguments to support the Court's continued use of canons of construction. ${ }^{60}$ One scholar has argued that, even if contrived, interpretive norms or canons of construction are inevitable in every area of modern law. $\mathrm{He}$ asserts that the words of a statute simply "cannot be interpreted without some sort of understanding about the background against which they are written." ${ }^{11}$ Even a fairly straightforward canon such as the one that requires courts to read the "plain meaning" of statutory terms can only approximate the intent underlying those terms. ${ }^{62}$

The argument supporting the use of canons is not meant to suggest that all canons are legitimate under all circumstances. Rather, it suggests that canons are not always illegitimate merely because they contain some element of contrivance. Canons can

${ }^{35}$ Llewellyn, 3 Vand L Rev at 399 (cited in note 54).

so Posner, $50 \mathrm{U}$ Chi L Rev at 811 (cited in note 45).

${ }^{67}$ Llewellyn, 3 Vand L Rev at 399.

s* Posner, $50 \mathrm{U}$ Chi L Rev at 817 (footnote omitted).

s9 Id at 801; Cass R. Sunstein, After the Rights Revolution: Reconceiving the Regulatory State 149-50 (Harvard, 1990). In addition, the Supreme Court cases referred to in this Comment demonstrate the current Supreme Court's use of canons of construction. See, for example, cases cited in note 64 .

${ }^{60}$ Sunstein, After the Rights Revolution at 150-57; William N. Eskridge and Philip P. Frickey, Cases and Materials on Legislation: Statutes and the Creation of Public Policy 693-95 (West, 1988); Felix Frankfurter, Some Reflections on the Reading of Statutes, 47 Colum L Rev 527, 544-45 (1947).

62 Sunstein, After the Rights Revolution at 149.

e2 Id at 152-53. 
serve as legitimate analytical tools for statutory interpretation when legislative guidance is lacking. Canons offer the best available approximation of legislative intent, especially when substantive justifications support their use. When used appropriately, canons limit the otherwise largely unlimited discretion that courts have in interpreting statutes. As one commentator suggested, "[e]ven when the traditional sources of interpretation leave gaps, courts should not resolve cases merely by deciding what result would in their view be best, all things considered. Instead, the legal culture should be taken to impose a degree of constraint on the selection of the governing principle." ${ }^{\text {(3) }}$ Canons of construction impose a degree of constraint on the judiciary.

2. The context canon of construction.

One canon of construction the Supreme Court has used offers guidance to courts faced with implication questions. This canon, the "context canon," directs courts to consider the context of a statute's enactment. ${ }^{64}$ The context comprises the set of legal norms that were in effect at the time the legislature enacted the statute. ${ }^{65}$ Those legal norms might include specific Supreme Court decisions, ${ }^{66}$ or even general principles commonly known to the legal culture at the time. ${ }^{67}$ Judges applying this "context canon" must recreate the legal context in order to understand the words of the statute in the same way the enacting Congress understood them.

In a recent case, Blatchford $v$ Native Village of Noatak, ${ }^{68}$ the Supreme Court examined the context of a statute's enactment in order to determine the intent of the enacting legislature. The native Alaskan villages contended that the statute at issue allowed abrogation of state sovereign immunity, thus permitting the villages to sue a state under the statute ${ }^{69}$ Although the Court could

${ }^{63}$ Id at 158.

64 The Supreme Court has used this canon many times, including in Cannon, 441 US at 698-99; Molzof v United States, 112 S Ct 711, 715-16 (1992); Franklin v Gwinnett County Public Schools, 112 S Ct 1028, 1035-37 (1992). See also John Paul Stevens, The Shakespeare Canon of Statutory Construction, $104 \mathrm{U} \mathrm{Pa} \mathrm{L} \mathrm{Rev} \mathrm{1373,} 1379-81$ (1992).

os Molzof, 112 S Ct at 716.

${ }^{68}$ See, for example, Blatchford $v$ Native Village of Noatak, 111 S Ct 2578, 2585-86 (1991).

${ }^{87}$ See, for example, Molzof, $112 \mathrm{~S} \mathrm{Ct}$ at 715 (looking to legal dictionaries from period of enactment to determine what the term "punitive damages" meant at the time).

68 111 S Ct 2578 (1991).

60 Blatchford involved a jurisdiction statute that granted native Alaskan tribes access to the federal courts. The native tribes in Blatchford sought to sue the State of Alaska under the statute. The state claimed that the Eleventh Amendment, which grants sovereign 
have decided the case simply by applying a current test requiring a "clear statement" of legislative intent, ${ }^{70}$ the Court instead examined the context of the statute's enactment to determine whether Congress relied on a similar or less stringent Supreme Court test. The Court reasoned that even if the enacting Congress intended to permit abrogation of state sovereign immunity, it would not have written a clear statement of that intent into the statute unless the Supreme Court at the time of enactment required such a statement. ${ }^{71}$ Finding no Supreme Court opinion from the time of the statute's enactment requiring one, the Court resorted to the clear statement test to resolve the case. ${ }^{72}$ Nevertheless, it is important to note that Justice Scalia carefully considered the context of the statute's enactment, and in fact used the current test only after determining that no test existed during the time of the statute's enactment.

The Court's use of the context canon presumes congressional awareness of Supreme Court decisions. In regard to this presumption the Blatchford Court wrote, "[w]e shall assume for the sake of argument (though we by no means accept) that Congress must be presumed to have had ... [a relatively obscure decision] in mind as the backdrop to all its legislation." "73 The Court accepted the presumption while acknowledging that it appeared to be contrived. In other cases using the context canon, the Court has also stated its acceptance of this presumption of congressional awareness. ${ }^{74}$ For example, in Cannon $v$ University of Chicago, the Court stated, "[i]t is always appropriate to assume that our elected representatives, like other citizens, know the law."

\section{The context canon and the ACAA.}

Courts can legitimately use the context canon to analyze implication issues under the ACAA. In the past, the Supreme Court created and used a variety of tests to decide whether to imply a

\footnotetext{
immunity to the states, barred the suit. The villages claimed that the statute implicitly abrogated state sovereign immunity on behalf of native tribes. Id at 2580-81.

70 The test current at the time of the Blatchford decision was Dellmuth v Muth, 491 US 223 (1989). See Blatchford, 111 S Ct at 2584-85.

$7111 \mathrm{~S} \mathrm{Ct}$ at 2585.

72 Id at $2585-86$.

73 Id at 2585 .

${ }^{74}$ See Molzof, 112 S Ct at 716, citing Morissette v United States, 342 US 246 (1952); Merrill Lynch, Pierce, Fenner \& Smith, Inc. v Curran, 456 US 353, 379 (1982), citing Cannon, 441 US at 696-97.

7641 US at $696-97$.
} 
private cause of action and corresponding damages under federal statutes. ${ }^{76}$ The context canon can help courts determine which particular test constituted the backdrop for the enactment of the ACAA.

Courts using the context canon must maintain the well-accepted presumption that the enacting Congress read and responded to contemporaneous Supreme Court opinions. ${ }^{77}$ In regard to the ACAA, the presumption that Congress knew about specific implication cases accurately reflects reality. The enacting Congress could hardly have ignored important changes and developments in the method of federal statutory construction. ${ }^{78}$ In addition, Congress closely monitored the Court's decisions regarding federal civil rights legislation. In fact, Congress enacted the ACAA itself in direct response to the Supreme Court decision in Department of Transportation $v$ Paralyzed Veterans of America. ${ }^{79}$ Thus, with respect to the ACAA, the context canon accurately describes congressional behavior and patterns of communication with the federal judiciary.

\section{The Context of Enactment and Implication of a Private Cause of Action under the Arr Carriers Access Act}

Because neither the statutory language nor the legislative history of the ACAA explicitly indicates legislative intent, ${ }^{80}$ this Section relies on the context canon of construction to determine whether a private cause of action is available under the ACAA. In order to ascertain the appropriate implication test for the ACAA, this Section briefly recounts the recent history of Supreme Court decisions establishing, applying, and overruling implication tests. This Section also discusses Transamerica Mortgage Advisors, Inc. $v$ Lewis, ${ }^{81}$ which provides the appropriate test for interpreting the ACAA, and applies it to the ACAA to determine whether private

${ }^{76}$ See cases cited in note 19.

77 See notes 73-75 and accompanying text.

78 Indeed, in the four years following the Court's decision in Cort $v$ Ash, the federal courts implied a private cause of action under at least twenty federal statutes. See Cannon, 441 US at 741 (Powell dissenting).

70 477 US 597 (1986). See 132 Cong Rec S 11784 (Aug 15, 1986)(statement of Senator Dole); 132 Cong Rec S 9899 (Jul 30, 1986)(statement of Senator Dole); 132 Cong Rec H 7193 (Sep 18, 1986)(statement of Representative Mineta).

so The ACAA contains no provision discussing private enforcement or available damages. See ACAA, 49 USC $\S$ 1374(c). Likewise, the legislative history contains no explicit discussion of private enforcement. See the legislative history cited in notes 1, 79.

81444 US 11 (1979). 
causes of action are available under the Act. The Transamerica test requires a more rigorous examination of intent than the test courts have used to interpret the ACAA.

\section{A. The History of Implication Doctrine}

At first glance, permitting a private cause of action under a statute that does not explicitly provide for one may seem unwarranted. However, during most of the twentieth century, the federal courts have implied private causes of action under federal statutes. Remarking on this tradition, the Court once wrote:

When Congress intends private litigants to have a cause of action to support their statutory rights, the far better course is for it to specify as much when it creates those rights. But the Court has long recognized that under certain limited circumstances the failure of Congress to do so is not inconsistent with an intent on its part to have such a remedy available to the persons benefited by its legislation..$^{82}$

\section{The Cort test.}

In Cort $v$ Ash, the Court created a four-pronged test for determining legislative intent to provide a private cause of action. ${ }^{83} \mathrm{~A}$ court first must determine whether the language of the statute indicates that Congress intended to grant a benefit to a particular class of people. ${ }^{84}$ Second, a court must ask whether the legislative history indicates intent either to create or to deny a private cause of action. Since the legislative histories of statutes involved in implication cases often lack explicit evidence of intent, ${ }^{85}$ the Cort test allows a mute or ambiguous history to serve as affirmative evidence of a legislative intent to create a private cause of action..$^{86}$ Third, a court must consider whether private enforcement would be consistent with the underlying purpose of the statute in question. ${ }^{87} \mathrm{Fi}$ nally, a court must examine whether the area of law the statute governs is one traditionally relegated to the states. If it is, then a

${ }^{82}$ Cannon, 441 US at 717.

${ }^{83} 422$ US at 78.

s4 Id at $78,80-82$.

Ss See notes $46-47$ and accompanying text.

36 Cort, 422 US at $78,82-84$.

${ }^{87}$ Id at 78,84 . 
private cause of action based on federal law would be inappropriate. ${ }^{88}$

Soon after Cort, the Supreme Court discovered that this test made the implication of private causes of action an alarmingly easy task. Indeed, federal courts implied private causes of action under no less than twenty separate federal statutes in just the first four years following the decision. ${ }^{89}$ In Cannon $v$ University of Chicago, decided about four years after Cort, Justice Powell most accurately described the shortcomings of the Cort test. He stated in dissent,

[t]he Cort analysis too easily may be used to deflect inquiry away from the intent of Congress, and to permit a court instead to substitute its own views as to the desirability of private enforcement. Of the four factors mentioned in Cort, only one refers expressly to legislative intent. The other three invite independent judicial lawmaking. ${ }^{90}$

\section{The Cort test overruled.}

In 1979, a few months after the Cannon decision, the Court effectively overruled use of the Cort test in Transamerica. ${ }^{91}$ The Transamerica test consists of only two prongs. The first prong of the Transamerica test seems to mirror the first prong of the Cort test. Under both tests, the first prong directs courts to ask whether the statute created a federal right in a particular class of people. ${ }^{\mathbf{9 2}}$ In Cort, however, the Justices presumed that when Congress created a federal right via statute, it also intended to create a private cause of action to enforce that right. In contrast, the Transamerica Court viewed the question of the creation of a federal statutory right merely as the threshhold for the second prong: a more direct investigation into legislative intent. Reiterating Justice Powell's concern in Cannon, ${ }^{93}$ the Transamerica Court stated that "whether Congress intended additionally that these [statutory]

sa Id at $78,84-85$.

Se Cannon, 441 US at 741 (Powell dissenting).

so Id at 740 (Powell dissenting). Justice Powell criticized each of the remaining prongs in detail. Id.

o1 444 US 11. Transamerica did not explicitly overrule Cort, but subsequent decisions indicate that the test was essentially overruled. See Thompson $v$ Thompson, 484 US 174, 189 (1988) (Scalia concurring) ("It could not be plainer that we effectively overruled the Cort $v$ Ash analysis in Touche Ross \& Co. $v$ Redington and Transamerica Mortgage Advisors, Inc. $v$ Lewis . . . .")(citations omitted).

${ }^{2}$ Transamerica, 444 US at 17-18.

${ }^{93}$ See note 90 . 
provisions would be enforced through private litigation is a different question" from the question whether a right exists. ${ }^{94}$ Thus, although the language of Transamerica's first prong tracks Cort, under Transamerica that prong is not dispositive.

The second prong of the Transamerica test requires a direct inquiry into legislative intent. This differs from the second prong of the Cort test, which only requires courts to examine the legislative history for indications of intent. Under Cort, a mute or ambiguous history can serve as a positive indication of legislative intent to create a private cause of action. ${ }^{95}$ In contrast, the Transamerica test instructs courts to look beyond the legislative history for positive evidence of implicit intent in the language of the statute and the circumstances of its enactment. ${ }^{96}$ The Transamerica Court also expressly rejected Cort's third and fourth prongs that looked to the underlying purpose of the statute and to state law. Thus, the Transamerica test squarely addresses Justice Powell's concerns in Cannon regarding the Cort test, because Transamerica focuses directly on legislative intent.

\section{The ACAA's context of enactment.}

In the early 1980s, the Court began once again to refer to the Cort test in cases in which the Court had been asked to imply a private cause of action..$^{97}$ However, the reappearance of Cort did not signal the demise of the Transamerica test because the Court relied on both tests in resolving implication issues. ${ }^{88}$ It is likely that the Court used the several prongs of the Cort test in these opinions to add credence to the decision to create or deny a private cause of action. Since the Cort test encompassed several prongs related to general policy considerations, ${ }^{9 \theta}$ the Court could call upon those policy justifications to add support to any decision.

Yet, in 1985, before Congress enacted the ACAA, the Court clearly rejected the Cort test in Massachusetts Mutual Life Insurance Co. $v$ Russell. ${ }^{100}$ In Massachusetts Mutual, the lower court

94 444 US at 18.

95 See text accompanying notes 85-86.

96 444 US at 18. This does not mean that courts should not look for explicit evidence of intent in the legislative history. The test merely recognizes that such explicit information will likely not exist.

'7 See, for example, Northwest Airlines, Inc. $v$ Transport Workers Union of America, 451 US 77, 90 (1981); California v Sierra Club, 451 US 287, 292 (1981).

- See Northwest Airlines, 451 US at 91; Sierra Club, 451 US at 293.

See notes 84-88 and accompanying text.

100473 US 134 (1985). 
relied on the Cort test to imply a private cause of action. The Supreme Court explicitly rejected use of the Cort test and instead applied the Transamerica test. The Court stated that "unless [] congressional intent can be inferred from the language of the statute, the statutory structure, or some other source, the essential predicate for implication of a private remedy simply does not exist."101 Thus, while the Court was not troubled in the past by references to Cort, it summarily rejected reliance on Cort alone. Instead, the Court made it clear that, the Cort test notwithstanding, the ultimate question in implication cases rested on the type of implicit intent the Transamerica test revealed. Thus, according to the context canon of construction, the standard the Court applied during the period of the ACAA's enactment-that is, the Transamerica test as applied in Massachusetts Mutual-should be used to determine implicit intent in the ACAA. ${ }^{102}$

\section{B. The Transamerica Test}

The Transamerica test starts with the threshold question whether Congress enacted the statute for the benefit of a particular class of people. ${ }^{103}$ However, its central feature is a direct inquiry into implicit legislative intent. ${ }^{104}$ This direct inquiry includes an examination of the language of the statute and of the circumstances of its enactment. ${ }^{105}$

1. Statutory language.

In Transamerica, the Court interpreted Sections 215 and 206 of the Investment Advisors Act of $1940 .{ }^{106}$ In $\S 215$, Congress de-

101 Id at 145, quoting Northwest Airlines, 451 US at 94.

${ }^{102}$ In 1988, the Court again referred to the Cort decision in an implication case. Thompson $v$ Thompson, 484 US 174, 179 (1988). Because the Court reintroduced the Cort test in this manner, current courts cannot be certain whether that test is valid or not. However, a court applying the context canon does not necessarily face this dilemma. For example, as the history of implication doctrine makes clear, the Transamerica test was the current test when Congress enacted the ACAA in 1986. Thus, courts interpreting the ACAA should apply the Transamerica test to determine whether a private cause of action and corresponding damages are available under the Act.

${ }^{103}$ Transamerica, 444 US at 17.

104 Id at 15-16.

105 Id at 18. In addition to these two factors, the Transamerica Court also considered the structure of the statute. However, because intent evidence gleaned from the structure of the statute can always be overcome by other evidence of intent, see id at 20-21, this evidence is not dispositive with respect to the ACAA.

${ }^{108} 15$ USC $\S \S 80 \mathrm{~b}-15$ and $80 \mathrm{~b}-6$ (1982). 
clared "void" those contracts created in violation of the Act. ${ }^{107}$ In analyzing that section, the Transamerica Court found that the term "voidness" necessarily carried with it the private right to a civil cause of action. ${ }^{108}$ The Court noted that, according to the common law of contract, a right to rescind creates in one party to a disputed contract a civil liability that the other party can enforce through litigation. ${ }^{109}$ Thus, the Court implied a private cause of action under $\S 215$ because that provision invoked terms that within the legal culture suggest the existence of a private cause of action. ${ }^{110}$

\section{Circumstances of enactment.}

The Transamerica Court also examined the language of $\S 206$ of the Investment Advisors Act, but found that the language alone did not indicate a legislative intent to create a private cause of action. The Court did not end its inquiry there, however, but in addition examined the circumstances of the statute's enactment for evidence of the requisite implicit intent. ${ }^{111}$ The Court looked to other securities statutes that Congress had enacted prior to the statute in question. ${ }^{112}$ The Court found that Congress had explicitly provided for private causes of action in each of the previously enacted statutes. ${ }^{113}$ Comparing Congress' treatment of those statutes with the statute at issue, which did not explicitly provide for such an action, the Court concluded that Congress would have explicitly

107 Section 215 still reads in part: "Every contract made in violation of any provision of this subchapter ... shall be void (1) as regards the rights of any person who, in violation of any such provision ... shall have made or engaged in the performance of any such contract ...."15 USC \& 80b-15 (1988).

108444 US at 18.

109 Id, citing Deckert $v$ Independence Shares Corp., 311 US 282, 289 (1940); Samuel Williston, A Treatise on the Law of Contracts $\$ 1525$ (Baker, Voorhis, 3d ed 1970). Furthermore, because an already existing body of law, the Securities Exchange Act, contained the terms used in the Investment Advisors Act, the Transamerica Court reasoned that Congress must have intended for the Court to interpret the statutory terms in a like manner. Transamerica, 444 US at 18-19.

11 For a similar line of reasoning, see Molzof, $112 \mathrm{~S} \mathrm{Ct}$ at 716, quoting Morissette, 342 US at 263 ("where Congress borrows terms of art in which are accumulated the legal tradition and meaning of centuries of practice, it presumably knows and adopts the cluster of ideas that were attached to each borrowed word in the body of learning from which it was taken and the meaning its use will convey to the judicial mind unless otherwise instructed").

$11144 \mathrm{US}$ at $19-21$.

112 Id at 20-21 n 10, citing the Securities Act of 1933, the Securities Exchange Act of 1934, the Public Utility Holding Company Act of 1935, the Trust Indenture Act of 1939, and the Investment Company Act of 1940.

11344 US at 20. 
provided for a private cause of action in the case at bar if it had intended to do so. ${ }^{114}$

Of course, the Court's observations about the circumstances of the Act's enactment might also be applied to $\S 215$, where the Court found an implicit private cause of action. The reasoning of the Court, however, demonstrates that only one positive indication of legislative intent is required.

\section{The ACAA Under the Transamerica Test}

This Section applies the Transamerica test to the ACAA and concludes that a private cause of action exists within the Act. In addition to the fact that Congress enacted the ACAA particularly for the benefit of people with disabilities, ${ }^{115}$ both the language and circumstances of enactment indicate an implicit intent to create such an action.

\section{Statutory language.}

Like the terms of $\S 215$ of the Investment Advisors Act in Transamerica, the terms used in the ACAA carry with them certain implicit attributes, including the right to a private cause of action. The terms of the Act afford private citizens protection from "discrimination."116 In an already existing body of constitutional law, a similar right to protection from discrimination arises out of the Fifth and Fourteenth Amendments. ${ }^{117}$ The Supreme Court has allowed private parties to enforce the constitutional right to equal protection through civil litigation. ${ }^{118}$ Thus, just as the Transamerica Court drew an analogy between the common law and the statute in question, courts interpreting the ACAA should draw a similar analogy between constitutional law and the ACAA. The analogy to constitutional law suggests that the ACAA implies a private cause of action because it invokes a concept-a ban on discrimina-

114 Id at 21.

11 See Tallarico, 881 F2d at 569. Under Transamerica, a court interpreting a federal statute should also ask the threshold question, whether Congress enacted the statute for the benefit of a particular class of people of which the plaintiff is a member. It is clear from the Act's face that it was enacted for the benefit of people with disabilities. The Act reads: "[n]o air carrier may discriminate against any otherwise qualified handicapped individual, by reason of such handicap. ..." 49 USC $\S 1374(c)(1)$ (emphasis added).

11849 USC \& 1374(c)(1).

117 See Ronald D. Rotunda, John E. Nowak, and J. Nelson Young, 2 Treatise on Constitutional Law: Substance and Procedure § 14.7 at 23-23 (West, 1986).

${ }^{118}$ See Davis v Passman, 442 US 228 (1979) (addressing Fifth Amendment equal protection). 
tion-that implies within the legal culture the existence of a private cause of action.

\section{Circumstances of enactment.}

The circumstances in which Congress enacted the ACAA also suggest an intent to create a private cause of action. Again, the circumstances of enactment include the backdrop of congressional decisionmaking, as evidenced by other statutes governing the same area of law as the statute in question. ${ }^{119}$ The ACAA is a civil rights law. ${ }^{120}$ Of the modern civil rights laws ${ }^{121}$ in force in 1986, the year the ACAA was enacted, nearly half (including Title VI of the Civil Rights Act of 1964, ${ }^{122}$ the Rehabilitation Act of $1973,{ }^{123}$ and Title IX of the Education Amendments of $1972^{124}$ ) were silent on the issue of private causes of action. Just as many, including the Fair Housing Act, ${ }^{125}$ and Titles $\mathrm{II}^{128}$ and VII ${ }^{127}$ of the Civil Rights Act of 1964, specifically provided for such actions. ${ }^{128}$ This fact alone might suggest that Congress intended to allow for private enforcement only in cases in which it had explicitly so provided. After all, it appears that Congress knew how to create a private cause of action if it chose to do so in the context of civil rights legislation.

However, by 1986, the federal courts had implied private causes of action under every contested civil rights statute that did not explicitly address the issue of enforcement. ${ }^{129}$ Under the Tran-

110 See notes 111-114 and accompanying text.

120 "This legislation, [Section 504 of the Rehabilitation Act, is] often referred to as the civil rights charter for individuals with disabilities. ... I strongly believe that this major gap in the protection that Section 504 affords . . . should be filled [by the passage of the ACAA]." 132 Cong Rec S 9901 (Jul 30, 1986)(statement of Senator Cranston)(emphasis added).

121 Modern civil right statutes (those enacted after 1964) are similar to the ACAA, not only because they were enacted within the same historical time period, but also because they govern the actions of private individuals rather than states or state actors. Theodore Eisenberg, Civil Rights Legislation: Cases and Materials 6 (Michie, 2d ed 1987).

12242 USC $\S \S 2000$ d et seq (1988).

12329 USC $\S \S 701$ et seq (1988).

12420 USC $\S 1681$ et seq (1988).

12842 USC $\$ \$ 3601$ et seq (1988).

12642 USC $\S \S 2000 a$ et seq (1988).

12842 USC $\S \S 2000$ et seq (1988).

${ }^{228}$ Fair Housing Act, 42 USC § 3613; Title II, 42 USC § 2000a-3; Title VII, 42 USC $\$ 2000 \mathrm{e}-5$.

120 See, for example, Cannon, 441 US at 694-703 (discussing Titles VI and IX of the Civil Rights Act of 1964); Note, Safeguarding Equality for the Handicapped: Compensatory Relief Under Section 504 of the Rehabilitation Act, 1986 Duke L J 197, 197 n 6 ("Courts of appeals in ten circuits have held that section 504 [of the Rehabilitation Act] implicitly confers a private right of action."). 
samerica test, this state of affairs indicates that the backdrop of congressional decisionmaking in 1986 included the presumption that courts would construe civil rights statutes to allow for private enforcement in the face of legislative silence. ${ }^{130}$ Given this interpretive background, it is likely that Congress would have explicitly denied a private cause of action in the language of the ACAA if it had so intended. Thus, given the circumstances of its enactment, the courts should construe the ACAA's silence regarding a private cause of action as a legislative intention to provide for such an action.

In addition, the circumstances of the ACAA's enactment indicate that Congress enacted the statute even though it knew that public enforcement procedures would not be put in place within the statutorily mandated time period. The legislative history includes a copy of a letter from the Department of Transportation that informed Congress that the Department might not be able to "issue final new or revised regulations within the 120-day deadline established by the bill." ${ }^{131}$ In fact, the DOT did not issue regulations until 1990, nearly four years after the ACAA's enactment. ${ }^{\mathbf{1 3 2}}$ Unless Congress anticipated some form of private enforcement, the passage of the Act without prompt public enforcement would have rendered the entire Act impotent. The passage of an unenforceable Act would have been particularly unacceptable to the Congress in this case. Because of the need to accommodate the disabled, Congress reacted uncharacteristically swiftly and decisively when it passed the ACAA. The legislation was a bipartisan effort that Congress enacted within one hundred days from the date it was introduced. ${ }^{133}$ Much of the debate in the Senate focused on the Senators' desire to guarantee the disabled equal access to air transportation as quickly as possible. ${ }^{134}$ The juxtaposition of Con-

130 Although this presumption contradicts the usual presumption in implication cases, see text accompanying note 52 , one commentator has noted that " $[t]$ he Supreme Court's general hostility to the creation of implied rights of action finds a conspicuous exception in the civil rights laws." Sunstein, After the Rights Revolution at 183 (cited in note 59).

131132 Cong Rec S 11785-86 (Aug 15, 1986).

132 See 14 CFR Part 382 (1992).

${ }^{233}$ See 132 Cong Rec S 19899-900 (Jul 30, 1986) (introduction of the ACAA in the Senate); 132 Cong Rec S 11787 (Aug 15, 1986) (passage of the ACAA by the Senate); 132 Cong Rec H 7195 (Sep 18, 1986) (passage of the ACAA by the House).

${ }_{134}$ See, for example, 132 Cong Rec S 11787 (Aug 15, 1986)(statement of Senator Metzenbaum) ("Over the years, the Department of Transportation has received numerous complaints about discriminatory treatment of handicapped persons by different commercial airlines. ... We have come a long way from the days when it was acceptable to treat persons with disabilities as second class citizens. Congress must act now to ensure that handicapped 
gress's decisive action with the anticipated lack of immediate public enforcement suggests that Congress expected the ACAA to be enforced, at least in part, through private causes of action.

\section{The Context Canon and the Implication of Available DAMAGES}

The courts interpreting the ACAA failed to use the context canon of construction when considering the issue of available damages. In 1983, the Supreme Court decided Guardians Assn. v Civil Service Comm'n, N.Y.C., ${ }^{138}$ which concerned implication of available damages in cases in which courts had already implied a private cause of action. Because Guardians was still good law when Congress enacted the ACAA in 1986, the courts construing the ACAA should have relied on that opinion when deciding the issue of available damages. ${ }^{136}$

An analysis of the ACAA using the Guardians test indicates that courts should make damages for emotional distress available to private plaintiffs, but deny the availability of punitive damages under the Act. This Section discusses the Guardians test and then applies that test, first to the issue of damages for emotional distress and then to the issue of punitive damages. In addition, the treatment of punitive damages includes an analysis outside of the canon of context.

\section{A. The Guardians Test}

In Guardians, the Court explicitly stated that the issue of damages in implication cases was "analytically distinct" from the issue of whether an implicit private cause of action existed. ${ }^{137}$ Thus, although courts should use the Transamerica test to explore the availability of both a private cause of action and damages, the two analyses should proceed separately.

In describing the analytical framework courts should use to determine available damages, the Guardians Court wrote: "[t]he usual rule is that where legal rights have been invaded and a cause

\footnotetext{
persons are not subjected to humiliating and degrading regulations or practices by any commercial air carrier or its personnel.").

${ }^{135} 463$ US 582, 584 (1983).

${ }^{138}$ Indeed, in a recent case in which the plaintiff sought monetary damages under Title IX of the Civil Rights Act of 1964, the Supreme Court, using the context canon of construction, followed the Guardians reasoning. Franklin v Gwinnett County Public Schools, 112 S Ct 1028, 1035-36 (1992).

${ }^{237} 463$ US at 595, citing Davis, 442 US at 239.
} 
of action is available, a federal court may use any available remedy to afford full relief. The general rule nevertheless yields where necessary to carry out the intent of.Congress or to avoid frustrating the purposes of the statute involved."138 Thus, under Guardians, a court interpreting the ACAA should presume that plaintiffs are entitled to full compensation for all harms suffered, including any emotional distress that resulted from the airlines' discriminatory behavior. The general presumption for full relief yields to a showing of a contrary legislative intent or a frustration of purpose. Thus, in the absence of such a showing, courts should grant full relief. ${ }^{139}$

To determine what damages Congress intended to make available, the Guardians Court applied the Transamerica test, the then current test for implicit intent. ${ }^{\mathbf{3} 0}$ The Transamerica test was also the current test when Congress enacted the ACAA in 1986. Thus, courts should use that test when determining implicit intent with regard to available damages under the Act. Notably, though, the Transamerica test operates differently when one asks whether damages are available, rather than whether an implied cause of action exists, due to the Guardians presumption in favor of full relief. When a court considers whether to imply a private cause of action, it generally begins with the presumption that a private cause of action does not exist. ${ }^{141}$ In contrast, when a court considers whether to imply damages, it begins with the Guardians presumption that full relief is available. Thus, when a court inquires into available damages, only an affirmative indication of an intent to deny full relief can override the Guardians presumption of its availability.

B. The Air Carriers Access Act and Damages for Emotional Distress Under Guardians

To determine whether Congress intended to contradict the Guardians presumption for full relief by denying recovery of emotional distress damages under the ACAA, courts should apply the Transamerica test. Under the Transamerica test, the backdrop of congressional decisionmaking for the ACAA can be discerned by

\footnotetext{
${ }^{138}$ Id, citing Bell $v$ Hood, 327 US 678, 684 (1946).

${ }_{138} 25$ CJS $\S 63$ (1966); 22 Am Jur 2d § 259 (1988).

140463 US at 599-600.

${ }^{141}$ See Thompson, 484 US at 190-91 (Scalia concurring). But see note 146.
} 
examining other similarly drafted civil rights statutes enacted prior to the ACAA. ${ }^{142}$

Similarly drafted statutes, namely those that in 1986 were silent on the issue of private enforcement, include Title VI of the Civil Rights Act of 1964, ${ }^{143}$ Title IX of the Education Amendments of $1973,{ }^{144}$ and the Rehabilitation Act of $1972{ }^{145}$ By 1986, courts had not conclusively answered the question whether plaintiffs could recover emotional distress damages under these statutes. ${ }^{146}$ The general confusion on this issue within the federal courts indicates that by 1986, the courts had yet to agree upon the significance of silence in civil rights statutes such as the ACAA with regard to the availability of emotional distress damages. Therefore, evidence from the context of enactment does not conclusively indicate a congressional intent to deny recovery of such damages, and thus does not rebut the Guardians presumption. Consequently, courts should award full compensatory relief, including damages for emotional distress, under the ACAA.

C. The Air Carriers Access Act and Punitive Damages Under Guardians

1. The ACAA in context: silence on punitive damages.

The Guardians presumption that courts should grant full relief does not include the presumption that punitive damages are recoverable. Unlike damages for emotional distress, punitive damages do not constitute compensation for injuries. ${ }^{147}$ Rather, courts

142 See notes $119-26$ and accompanying text.

14342 USC $\$ \S 2000 d$ et seq.

144 20 USC $\$ \$ 1681$ et seq.

1429 USC $\$ \$ 701$ et seq.

${ }_{146}$ See Eastman v Virginia Polytechnic Institute, 939 F2d 204, 206 (4th Cir 1991) (discussing the division of courts over the nature and extent of recoverable damages under both Title VI of the Civil Rights Act of 1964 and the Rehabilitation Act).

Several courts have granted monetary damages under the Rehabilitation Act. See Smith v Barton, 914 F2d 1330 (9th Cir 1990); Miener v State of Missouri, 673 F2d 969 (8th Cir 1982). Others have denied the recovery of such damages. See Rhodes $v$ Charter Hospital, 730 F Supp 1383 (S D Miss 1989); Shuttleworth v Broward County, 649 F Supp 35 (S D Fla 1986); Longoria v Harris, 554 F Supp 102 (S D Tex 1982).

The courts are equally divided with regard to Title IX of the Civil Rights Act of 1964. See Pfeiffer v Marion Center Area School District, 917 F2d 779 (3d Cir 1990) (holding compensatory damages available); Franklin v Gwinnett County Public Schools, 911 F2d 617 (11th Cir 1990) (denying damages).

147 See Black's Law Dictionary 390 (West, 6th ed 1990); W. Page Keeton, ed, Prosser and Keeton on the Law of Torts $\S 2$ at 9 (West, 5th ed 1984). 
assess punitive damages to punish the defendant and to deter others from acting in a similar manner. ${ }^{148}$

Because the Guardians presumption does not apply to punitive damages, courts should look for some indication of legislative intent to allow recovery of such damages. By applying the Transamerica test in this context, courts can determine whether the ACAA was intended to provide for punitive damages.

Transamerica directs courts to look for implicit intent in the circumstances of enactment as evidenced by the terms of other statutes enacted prior to the ACAA. ${ }^{149}$ Of the modern civil rights statutes enacted prior to 1986 (including Titles II, VI, and VII of the Civil Rights Act of $1964,{ }^{160}$. the Rehabilitation Act of $1973,{ }^{161}$ Title IX of the Education Amendments of $1972,{ }^{162}$ and the Fair Housing Act ${ }^{153}$ ) only the Fair Housing Act provides for the recovery of punitive damages. ${ }^{154}$ In addition, in 1986, courts did not permit recovery of punitive damages under statutes that were silent on the issue. ${ }^{155}$ Thus, the backdrop of congressional decisionmaking in 1986 included the presumption that statutory silence indicated an intent to deny the availability of punitive damages. The silence of the ACAA on the issue of punitive damages therefore must be construed as an indication of Congress's intent to deny the recovery of such damages.

2. Out of the context canon: Other civil rights statutes.

Generally, courts construe federal statutes so that they do not contradict other federal statutes regulating the same area of law. ${ }^{156}$ The ACAA is a civil rights statute. ${ }^{157}$ An examination of the modern federal civil rights statutes enacted after 1986, including the

${ }^{148}$ Black's Law Dictionary at 390 (cited in note 147); Keeton, ed, The Law of Torts $\S 2$ at 9 (cited in note 147).

149 See text accompanying notes 95-96.

${ }_{160}$ Title II, 42 USC $\$ \S 2000$ a et seq; Title VI, 42 USC $\$ \S 2000$ d et seq; Title VII 42 USC $\S \S 2000$ e et seq.

15129 USC $\$ \$ 701$ et seq.

${ }^{152} 20$ USC $\$ \S 1681$ et seq.

18342 USC $\$ \S 3601$ et seq.

16442 USC $\$ 3613(\mathrm{c})(1)$.

${ }^{155}$ Using Title VII as an example, see James D. Ghiardi and John J. Kircher, 2 Punitive Damages Law and Practice $\$ 15.27$ at 50 (Callaghan, 4th ed 1985).

${ }^{158}$ While recognizing that Congress "does not, of course, merely enact general policies," the Court has decided to enforce legislative policies. Miles $v$ Apex Marine Corp., $111 \mathrm{~S} \mathrm{Ct}$ 317, 321 (1990), quoting Moragne v States Marine Lines, Inc., 398 US 375, 392 (1970).

167 See note 120 and accompanying text. 
Americans With Disabilities Act ("ADA"), ${ }^{168}$ reveals a consistent policy to deny the recovery of punitive damages under civil rights legislation. ${ }^{139}$ This policy first took shape in 1964 with the enactment of Titles II, VI, and VII of the Civil Rights Act of $1964,{ }^{180}$ and has survived through the present day with the enactment of the ADA. ${ }^{181}$ In fact, punitive damages are only explicitly available under the Fair Housing Act ${ }^{162}$ and the Civil Rights Act of 1991. ${ }^{163}$ The ACAA, however, does not contain any provision that explicitly grants the right to recover punitive damages. A court granting punitive damages under the ACAA would directly contradict the tenets of a well-developed body of statutory law. Denying recovery of punitive damages under the ACAA represents the most consistent and clear reading of the statute.

\section{Conclusion}

This Comment uses a canon of statutory construction to interpret the ACAA and to determine whether a private cause of action, damages for emotional distress, and punitive damages are available under the Act. Courts should use the canon set forth in this Comment when addressing implication issues, both in the context of the ACAA and in the context of other federal statutes. When the appropriate canon is used to interpret the ACAA, it becomes clear that a private cause of action and emotional distress damages are implicitly embodied in the Act, while punitive damages are not. Courts using the appropriate canon to interpret other federal statutes can decide important questions concerning the scope of such statutes without requiring explicit new legislation to clarify implicit directives.

158 42 USCA $\$ 12188$ (b) (West, 1992 Pamphlet).

180 Punitive damages have been awarded under the Civil Rights Acts of 1866, 1870, and 1871. Linda L. Schuleter and Kenneth R. Redden, 2 Punitive Damages $\S 19.3(D)$ at 342 (Michie, 2d ed 1989). However, under the modern civil rights statutes (those enacted from 1964 through the present), punitive damages have only been available when explicitly granted by Congress or when sought in conjunction with a claim brought under Civil War era statutes. See in regard to Title VII, Ghiardi and Kircher, 2 Punitive Damages $\$ 15.27$ at 26 (1991 Supp) (cited in note 155); Keller v Prince George's County, 827 F2d 952, 955 (4th Cir 1987). Title VII illustrates this point particularly well because it is the most frequently litigated civil rights statute.

${ }_{160} 42$ USC $\$ \$ 2000 \mathrm{a}$ et seq; 42 USC $\$ \S 2000 \mathrm{~d}$ et seq; 42 USC $\$ \$ 2000$ e et seq, respectively.

${ }^{181} 42$ USCA $\$ \S 12188$ (b).

16242 USC \& $3613(\mathrm{c})$.

${ }^{163} 42$ USCA $\S 1981 \mathrm{a}(\mathrm{b})$. 
